\title{
Government Expenditure and Economic Growth in Nigeria: a Disaggregated Analysis
}

\section{Samuel Daniel Ugochukwu ${ }^{1}$, Lawrence Igwe Oruta ${ }^{1}$}

\author{
${ }^{1}$ Ebonyi State University \\ PMB 053, Abakaliki, Nigeria
}

DOI: $10.22178 /$ pos. $76-6$

JEL Classification: E31

Received 27.10.2021

Accepted 25.11.2021

Published online 30.11.2021

Corresponding Author:

Samuel Ugochukwu Daniel

samuelug01995@gmail.com

(c) 2021 The Authors. This article is licensed under a Creative Commons Attribution 4.0 License @ (i)

\section{INTRODUCTION}

Keynesian economics brought the government into the spotlight of economic affairs since the 1930s. In almost all economies of the world today, the government have taken a decisive and critical role. One primary reason for the change from the pre-Keynesian era was the market failure of the late 1920s, which resulted in arguably the worse economic downturn in history. The market had failed to regulate itself. Against the classical thought, over-production was due to falling demand, which resulted in unemployment

\begin{abstract}
Government expenditure is an essential instrument for achieving full employment, price stability, improved standard of living, economic growth and other macroeconomic objectives. However, questions regarding the efficacy of government expenditures to attain these objectives have continued to rise due to the alarming rate of unemployment, inflation, poverty and other socio-economic problems in Nigeria. This has called for the need to investigate the allocation of resources to some selected sectors and their resultant impact on the Nigerian economy. This study examined the effect of various components of Government Expenditures on Economic Growth in Nigeria for periods between 1981 and 2020. The analysis was based on Secondary data. The study adopted the Error Correction model and Granger Causality Test. The short-run model revealed that the components of government expenditures like recurrent expenditures on agriculture, health and education have an insignificant negative impact on economic growth. Recurrent expenditure on debt servicing and road and construction indicated a positive and negligible impact on economic growth. Concerning capital expenditures, government capital expenditures on social services were shown to have a negative and significant impact on economic growth. In contrast, government capital expenditures on economic services indicated a positive and insignificant impact on economic growth in Nigeria. In the long run, all the components of government expenditures employed showed a significant effect on economic growth. The research finding establishes no clear conclusion about whether Keynesian or Adolf Wagner's law is operational in Nigeria. The study concludes that the Nigerian economy is on the wrong path to sustainable growth and development. The study recommends that the government should increase its allocations to priority sectors like health, education, agriculture and infrastructures. Furthermore, the government should stimulate investment and output using monetary and fiscal policies to increase internally generated revenue and reduce government borrowing. Lastly, the study emphasises the need to improve government spending efficiencies, transparency in budgetary processes, and strict monitoring of government projects.
\end{abstract}

Keywords: government expenditures; social services; financial services; human capital development; economic growth.

and a decline in income and output. The market failed to achieve full employment. This event questioned the "let be" or laissez-faire policy that existed. There was then the need for a central body to set the rule of the game and take actions that directly and indirectly affect the economy, "government". Authors [4] noted that the perceived failure of the market system to efficiently and equitably allocate economic resources for social and infrastructural development is one reason for government involvement in the economy. One of the primary instruments that the 
government use in regulating the economy is government spending. The instrument of government expenditure is used to achieve macroeconomic objectives like full employment, price stability and sustained economic growth. The government also uses its expenditure to provide public goods like education, health, infrastructures, etc., which helps reduce socio-economic imbalances. Authors [17] commented that government expenditure is a fiscal instrument that serves a valuable role in controlling inflation, unemployment, depression, the balance of payment equilibrium, and foreign exchange rate stability. Government spending is used to raise aggregate demand in periods of depression and unemployment, further stimulating employment and output [7].

The government's interference in the economy does not automatically guarantee stability. However, it reduces the rate of instability. For instance, the government involvement in the economy did not prevent the oil shock of the 1970s, the financial crisis of 2007, Nigeria's economic recession of 2016 or the global recession of 2020 . However, the government's involvement makes it easy for nations to bounce back after these shocks.

The government roles have become more relevant in developing countries where income, output and employment are low. These countries are characterised by internal and external imbalances and instability, lack of social amenities, poor human capital development, and high poverty rates, thus, making government an essential agent of reducing the socio-economic problems these countries face. Authors [7] commented that developing countries' governments have embarked on various spending programs to achieve economic growth. However, as pointed out by the authors, there is no consensus on the exact effect of government expenditure on economic growth. For instance, while Keynesian economics proposes the intervention of government to stimulate the economy, especially in periods of downturn, authors [20] explained that the Classical school of thought considered fiscal policy as ineffective in ensuring macroeconomic growth on the grounds of crowding-out effects. Authors [21] noted that government intervention might slow down the economy's overall performance. The authors stated further that the government might increase taxes and/or borrowing to fi- nance rising expenditure. Taxation discourages work while government borrowing burdens future generations, especially if the borrowed resources are not productive. Thus, there is a tendency to misallocate resources by the government, which impedes national growth [21]. For the stages of development, Keynes established a link based on the short run from government expenditure to economic growth. In contrast, Adolf Wagner's law of increasing state activities explained that the increased government expenditures result from economic growth or increased economic activities, which is, in order words, a long-run analysis.

In Nigeria, government expenditures are in the form of capital and recurrent costs. These are further categorised into administration, social and community service, financial services and transfers, [10].

Authors [20] defined government recurrent expenditures as expenses on administration such as wages, salaries, interest on loans, maintenance etc., whereas capital expenditures are expenses on capital projects like roads, airports, health, education, telecommunication, electricity generation etc. Authors [5] defined economic growth as the increase in output of an economy capacity to produce goods and services needed to improve the welfare of the citizens of the country. Thus, the ultimate goal of economic growth is to make the people better off.

Most empirical studies have focused attention on analysing the aggregate of capital and recurrent expenditures. Some claimed that capital expenditures promote economic growth than recurrent expenditure. For instance, [20] noted government expenditure on health and education raises labour productivity and increases the development of national output. In a similar vein, government capital expenditures reduce private costs and thus, stimulate investment, promoting economic growth [20]. It is also argued that when capital stock exceeds the provision of consumer goods, the resultant effect is a recession. Thus, there is the need to balance the allocations of funds to recurrent and capital components expenditure. It is noteworthy that aggregating costs into capital and recurrent segments can be misleading because individual sectors of government expenditures do not have the same weight of influence on economic growth. 
There has been an annual increase in government expenditure in Nigeria, but there are still public outcries over decaying infrastructural facilities [18]. The poverty rate has remained high, with inflation and unemployment increasing at alarming rates. The rising government expenditures have not significantly contributed to the economic growth in Nigeria, as more than $50 \%$ of Nigerians live below the $\$ 2$ per day benchmark [18]. Economic growth rates have continued to stagger between positive and negative territories. In recent years, population growth rates have outweighed output growth rates. The growth rates have not been consistent with the increasing rate of government expenditure. [15] wrote that government expenditure growth rate was $37.9 \%$ in 2008 , before dropping to $6.4 \%$ in 2009 and increased to $21.5 \%$ in 2010 , and then started declining from $12.3 \%$ in 2011 to $-2.3 \%$ in 2012 while the growth rate of the GDP was $6.0 \%$ in $2008,7.0 \%$ in $2009,8.0 \%$ in $2010,7.4 \%$ in 2011 and $6.6 \%$ in 2012. However, from 2011 to 2019 , it grew by $181.35 \%$. GDP growth rate averaged at $3.15 \%$ from 2010 to 2020 with recessions of $-1.62 \%$ and $-1.79 \%$ in 2016 and 2020 respectively, [10]. Terms of trade have remained unfavourable while the balance of payment has been mostly deficits. Rising expenditures have brought about rising internal and external debt profiles, which creates a burden for future generations, thus defeating the idea of achieving sustainable development and deviating from the ultimate goal of economic growth, making the people better off. Nigeria's poor ranking in the $\mathrm{Hu}-$ man Development Index has reflected the poor state of education and health sectors in Nigeria. Between 2005 and 2019, Nigeria's HDI value has only increased from 0.465 to 0.539 , an increase of $15.9 \%$ [23]. The agricultural sector has also underperformed as Nigeria remains a major importer of food commodities.

Several empirical findings have also proven to be inconsistent. No consensus has been established on the exact relationship between economic growth and government expenditures or the amount of government expenditure required to stimulate economic growth. Empirical studies have produced divergent results. For instance, authors [20] found that Government Capital Expenditures was inversely related to RGDP in the short-run and the long run. The recurrent component was positively associated with RGDP in the long and short run. A study by [21] shows an inverse relationship between government expenditures on health and economic growth.

In contrast, government expenditure on the education sector was shown to be is seen to be insufficient to cater for the expanding industry in $\mathrm{Ni}$ geria. Authors [24] found out that none of the components of government expenditures contributes to economic growth in the short run. Still, in the long run, government expenditure on defence retards economic growth, and government expenditure on agriculture promotes economic growth. In contrast, government expenditure on education and transport/communication has no long-term impact on economic growth.

Therefore, it is essential to examine further the impact of government expenditures on the economic growth in Nigeria. Accordingly, the study adopts a disaggregated analysis.

\section{Objectives of the Study}

The primary objective of this study is to examine the impact of public expenditure on the economic growth of Nigeria. While the specific goals include to:

1. Assess the extent to which expenditures on Education (EDU) affects economic growth

2. Examine the extent to which government expenditures on Health (HLT) affects economic growth.

3. Determine the effect of government expenditures on Agriculture (AGR) on economic growth.

4. Evaluate the extent to which Public Debt Servicing (PDS) affects economic growth.

5. Understand the relationship between government expenditures on road and construction on economic growth in Nigeria.

6. Examine the impact of capital expenditures on social (CAPSO) and financial services (CAPSEC) on economic growth.

\section{Review of Related Literature}

Conceptual Review. According to [7], government expenditure is the government's costs for providing and maintaining itself as an institution, the economy, and society. They further stated that government expenditures tend to increase with time as the economy becomes large and 
more developed or as a result of an increase in its scope of activities.

In Nigeria, government expenditures are in the form of capital and recurrent costs. These are further categorised into administration, social and community service, financial services and transfers, [10].

Administration. The administrative category comprises general administration, defence, internal security and national assembly.

Social and Community Services. This consists of government expenditures on health, education and other social and community services. Therefore, this session plays a critical role in deciding the level of human capital development in Nigeria.

Economic Services. Government expenditures on agriculture, road and construction, transport and communication and other economic services are grouped in this category.

Transfers. This includes public debt servicing (including domestic and foreign), pension and gratuities, FCT/other/other CFR charges, contingencies and subventions [10].

Economic growth is the quantitative and sustained increase in a country's per-capita output or income accompanied by an increase in the labour force, consumption, and trade volume. As defined by [22], economic growth increases the market value of goods and services produced by the economy over time. GDP growth rate is mainly used as a measure of economic growth. Positive change in GDP indicates economic progress and, as such, desirable, while negative change indicates contraction.

Between 1960 and 1970, the Nigerian economy recorded an annual growth rate of $3.1 \%$. The growth rate went as high as $6.2 \%$ between 1970 and 1978 due to the oil boom. However, in the 1980s, the Nigerian economy had negative growth rates. The economic adjustment policy of 1986 was reflected in the positive growth rate of about 4\% between 1988 and 1997 [11]. The economy grew by an average of $7.7 \%$ between 2000 and 2010, with a peak of $15.3 \%$ in 2002 . GDP growth rate averaged at 3.15\% from 2010 to 2020 with recessions of $-1.62 \%$ and $-1.79 \%$ in 2016 and 2020 respectively, [10].

\section{Government Expenditure on Selected Sectors.}

The trend lines below show that the agricultural sector has received lesser budgetary allocation among the three industries, whereas the educational sector received the most funding. During the 1960s and 70s, the agricultural sector contributed largely to GDP, export revenue and employed over $60 \%$ of Nigerians. However, the discovery of crude oil has drawn attention away from the agricultural sector. Due to the poor performance of the agricultural sector, Nigeria has remained a significant importer of roughly all food commodities.

Government recurrent expenditures to health and education witnessed a boost from 2000 . However, these have been dramatically below the $15 \%$ and $26 \%$ benchmark to health and education, respectively. The health and education sectors experienced a significant rise in budgetary allocation starting in 2016/17; however, expenditures to the agricultural industry only improved marginally. Declines in these trends are observed in 2019 and 2020 due to decreased government revenues.

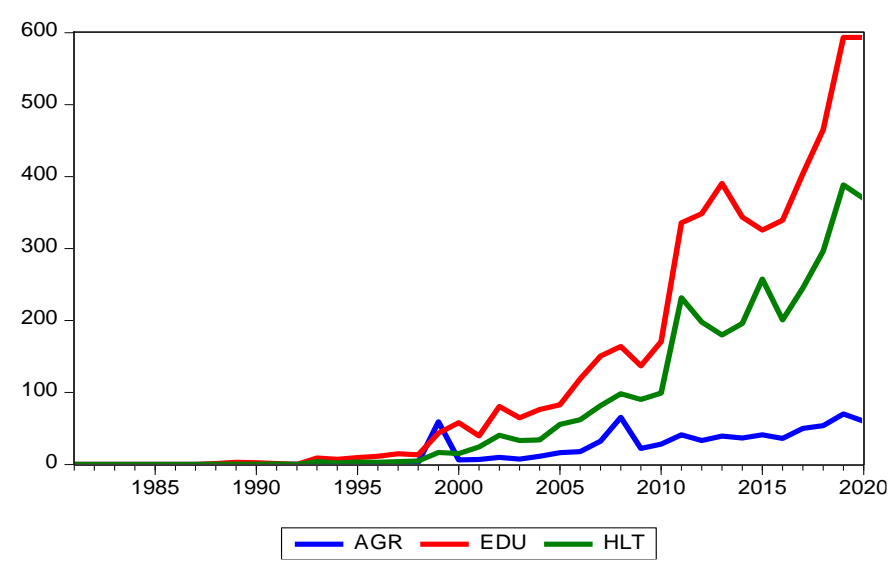

Figure 1 - Trends of Recurrent Expenditures on Agriculture, Education and Health [10]

Author [14] noted that in the year 2000, the budget for education was $9.6 \%$ which was further reduced to $6.3 \%$ in $2005,8.7 \%$ in 2007 and about $8 \%$ in 2012 . According to [9], government expenditure on education declined from $7.14 \%$ in 2018 to $7.11 \%$ in 2019 and then to $6.48 \%$ in 2020 , while government total spending on health was less than 5\%. The Nigerian budget directed towards the educational and health sector has continually been below $26 \%$ on education and $15 \%$ on health as recommended by the United Nations and the World Health Organization. Author [14] further opined that the policies directed towards education and health have not signifi- 
cantly impacted due to structural defects in the Nigerian economy, particularly the oil windfalls.

Human Capital Development in Nigeria. It is believed that significant investment in human capital is compulsory if a nation seeks to attain economic development. This is because human capital constitutes the most valuable resource of a country; in its absence, there will be the nonperformance of physical capital (tools, machinery, and equipment) which will impede economic growth [13; 14]. However, little attention has been paid to human capital development in Nigeria; this is as shown by low government expenditures on health and education and reflected in the Human Development Index.

The United Nations recommended that developing countries invest a minimum of $26 \%$ of national income on education while the World Health Organisation specified at least $15 \%$ on health. It is seen that government expenditures on health and education in Nigeria are far below these benchmarks. The low investment in these sectors is reflected in the poor state of existing infrastructures, lack of modern equipment and infrastructures in these sectors, continues outcry of workers on non-payment of salaries, and other enumerations, resulting in the low overall performance in these sectors. Nigeria was placed in 158th position out of 182 countries on United Nations Development Program report (2009). Nigeria was rated 10th out of 10 developing countries selected in that report. The human development index (HDI) report of 2011 showed that Nigeria ranked 156 with a value of 0.459 among 187 countries, while in 2013, Nigeria ranked 153 with a value of 0.471 among 187 countries. The United Nations Development Programmes (UNDP) 2019 report placed Nigeria in the 158th position underneath the low Human Development category [23]. Between 2005 and 2019, Nigeria's HDI value increased from 0.465 to 0.539 , an increase of $15.9 \%$. The 2020 ranking maintained the country's low human development category positioning it at 161 out of 189 countries and territories [23].

Capital Expenditures. Historical data reveals that capital expenditure about total expenditure has been falling over the last two decades while recurrent spending has been on the rise. However, this does not show that capitalist development in terms of infrastructure is sufficient or enough to boost the economy. On the contrary, the necessary infrastructures to drive the economy are scarce and deteriorating.

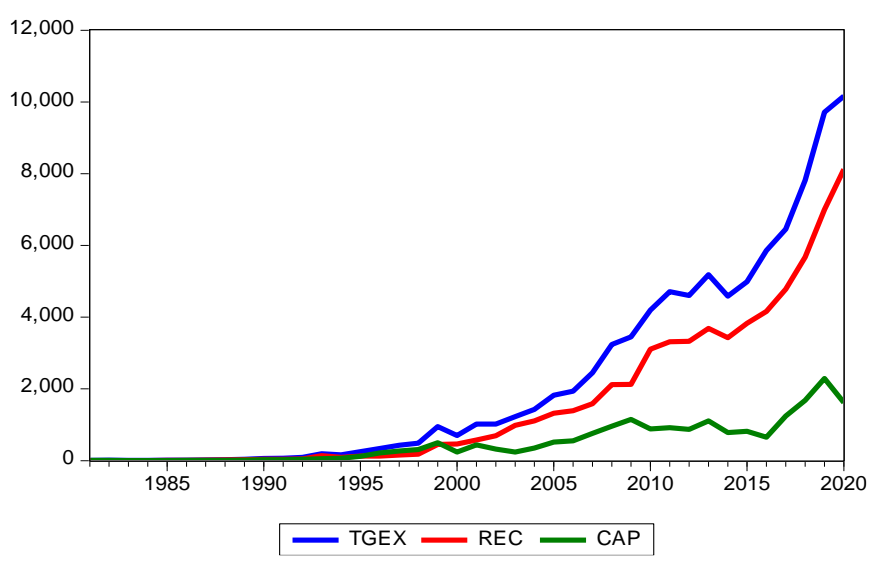

Figure 2 - Trends on Total Government Expenditure and Capital and Recurrent Expenditures

The figure above shows how poorly capital expenditures have been. Politicians may claim that government capital expenditures have been improved but comparing the rate of increase to that of recurrent expenses or as a ratio of total costs reveals that there has not been any significant improvement in government capital expenditures. For example, author [12] stated that capital expenditures as a percentage of GDP decreased steadily from $20.48 \%$ in 1980 to $6.27 \%$ in 1995. Between 1999 and 2010, it had fallen to a low of $0.30 \%$, from $5.23 \%$ in 2000 .

Public Debt Servicing. As seen in figure 3, Nigeria's debt service payment was very low up to the year, 2000 after which it rose steadily, mostly from 2009. Debt servicing has taken a massive bite on the Nigerian economy. It represents a substantial annual leakage from the Nigerian economy to service external debts. Internally, it means a reallocation of funds.

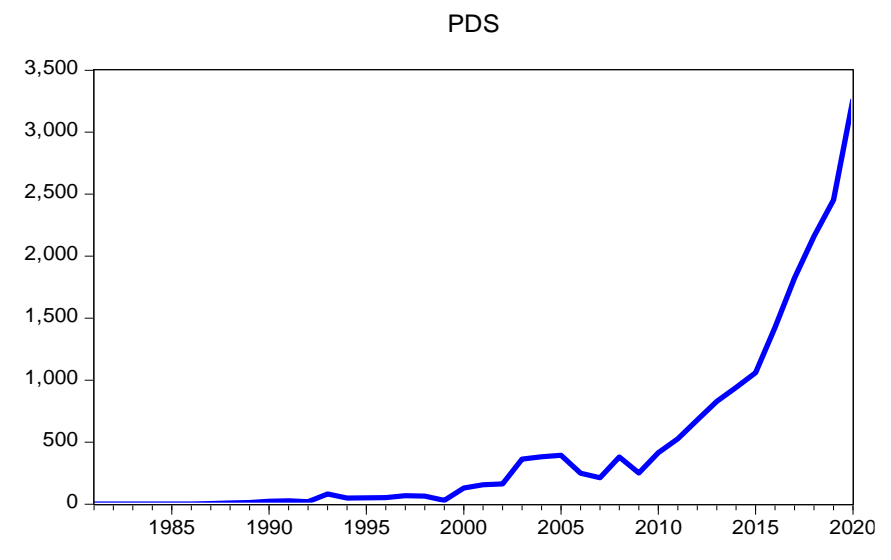

Figure 3 - Trend on Public Debt Servicing in Nigeria (1981-2020) 
Theoretical Review. The classical school of economic thought dominated economic literature before the great depression. This school argues that the government should perform only the primary function of providing security and the administration of justice. Outside these functions, government expenditures were considered waste and harmful to the economy. Their assumption of money neutrality emphasised that an increase in money supply will result in no change in the output; instead, it will result in inflation. To them, government spending crowds out private consumption and investment. They believed that the economy was better left alone; this brought about the Laissez-faire policy.

One of the earliest theories of government expenditure was developed by a German economist, Adolf Wagner (1835-1917). This law states that there are inherent tendencies for activities of different layers of governments to increase both intensively and extensively [12]. The theory establishes a linkage from industrialisation, urbanisation and education to the expansion of the public sector [15].

The theory explains that government expenditures on administration and regulation increase as an economy become more industrialised. The development of modern industrial society would give rise to increasing political pressure for social progress and call for increased allowance for social consideration in industry conduct [15]. Public expenditures increase more than the proportional increase in national income, which will expand the public sector. This theory establishes causality from economic growth to public spending and is a long-run analysis.

Musgrave's Theory of Public Expenditure Growth explains that the demand for public goods increases as per capita income increases. At low per capita income levels, the demand for public goods is small because such low income is devoted to satisfying primary needs. However, as income improves, the demand for public goods like education, transportation, health, regulation and other maintenances [15]. This theory supports Adolf Wagner's law that government expenditures tend to rise as the economy improves. However, [15] pointed out that with high per capita income typical in developed nations, public spending falls as most basic wants are satisfied.

The Wiseman and Peacock hypothesis, built on Wagner's law, also validates Wagner's rule in the
UK between 1891 and 1955. Their theory explained the increase in government expenditures from the socio-political viewpoint [15]. This hypothesis emphasised that government expenditure does not follow a smooth path. Instead, it jumps at discrete intervals due to political instability. For instance, during times of war, taxation tends to increase to fund government expenditures. However, the increased tax rate was unchanged after the war because people became used to it. Therefore, peacock and Wiseman conclude that government revenue is a function of government expenditures. The more the government generates revenue, the greater they spend on the economic welfare of the citizen [18].

The market failure of the 1930s questioned the validity of classical doctrine that the market should be left alone. The Keynesian theory was a demand-side theory as against the classical supply-side theories. Keynes proposed increasing government expenditure to stimulate aggregate demand to economic recovery through the multiplier effect. This was given as a remedy to countries experiencing economic recession. Contrary to Wagner's law, the Keynesian theory established causality from government expenditures to economic growth. However, [19] pointed that government consumption may crowd out private investment, dampen economic stimulus in the short run and reduce capital accumulation in the long run.

Different viewpoints have been established to explain the relationship between government expenditures and economic growth. No clear line has been drawn, no consensus, different perspectives and different conclusions.

Empirical Review. Public sector economics is considered one of the most researched areas in economics. Various research works have tried to ascertain the precise effect of government on the economy. This session reviews some of the researcher findings by some researchers.

Author [20] investigated the impact of government expenditure on economic growth in Nigeria between 1981 and 2016. The researchers employed the ordinary least square method. They found that government capital expenditures were inversely related to RGDP in the short and long run. In contrast, recurrent government expenditures were positively associated with RGDP in the long and short run. Authors [21] investigated the empirical relationship between gov- 
ernment expenditure and economic growth using OLS techniques. They found an inverse relationship between government expenditures on health and economic development. In contrast, government expenditure on the education sector was shown to be insufficient to cater to Nigeria's expanding industry. A study by [18] revealed the existence of bi-directional causality between economic growth and government expenditure on administration and between economic growth and government expenditure on financial services in Nigeria. Authors [3] employed Error Correction Model to examine the impact of government expenditure on Nigeria's economic growth for 1984-2015. Their results showed that public (recurrent and capital) expenditure has a significant positive effect on the economy's growth in the long run and an insignificant negative impact on the Nigerian economy. Authors [6] employed an autoregressive distributed lagged model and granger causality test in examining the effects of government expenditure on economic growth in Nigeria using time series data from 1970 to 2017. Their findings revealed that capital and recurrent are statistically significant, and hence these are the essential variables in explaining the impact of government expenditure on economic growth. The Granger causality test demonstrates a unidirectional causality from government expenditure to economic growth, invalidating the Keynesian theory. [19] concludes that a long-run relationship exists between government expenditures and economic development in Nigeria. Authors [15] found out that government expenditure has a positive and significant impact on economic growth. A study by [1] found out that total government expenditure, total recurrent expenditure and expenditure on education have adverse effects on economic growth. In contrast, spending on transport, communication, and health have a significant positive impact on economic growth in Nigeria. Authors[2] found that economic growth had a positive and meaningful linear relationship with recurrent expenditure and a negative but and significant relationship with capital expenditure in the short run. However, the connections were positive and statistically significant in the long run. A study by [8] found that social and economic services had a negative and insignificant effect on economic growth while the administration was positive and significant [3].

\section{METHODOLOGY}

This study employed an ex-post factor research design. This is because the study aimed at exploring cause and effect relationships. Secondary data obtained from CBN Statistical Bulletin, and World Bank Development Indicators, 2020 were used for the empirical analysis. Gross Domestic Product growth rate (GDPG), Government Recurrent Expenditures on Education (EDU), Health (HLT), Agriculture (AGR), Public Debt Servicing (PDS), Road Constructions (RC) and Government capital expenditures of Social Services (CAPSO) and Economic Services (CAPEC) were the variables used. The study covers a sample period from 1981 to 2020.

The model specification is based on the Keynesian theory, which states that economic growth is a positive function of government expenditure. Keynes (1936) regarded government expenditure as an exogenous variable that stimulates growth in the short run. The Keynesian national income model is given as follows:

$$
Y=C+I+G
$$

where $Y$ represents national income; $C$ - private consumption expenditure; $I$ - private investment; $G$ - government expenditure.

For the sake of this research, the Keynesian model (all things being equal) will be given as follows:

$$
Y=\beta_{0}+G
$$

The functional relationship is given as: $G D P G=f(E D U, H L T, D F S, A G R, P D S, C A P S O, C A P S E C)$

The mathematical specification of the model for the study is as follows:

$G D P=\beta_{0}+\beta_{1} E D U+\beta_{2} H L T+\beta_{3} A G R+\beta_{4} P D S+$ $+\beta_{5} R C+\beta_{6} C A P S O+\beta_{7} C A P E C$

While the log linearised econometric model is given as:

$$
\begin{aligned}
& L G D P G=\beta_{0}+\beta_{1} L E D U+\beta_{2} L H L T+\beta_{3} L A G R+ \\
& +\beta_{4} L P D S+\beta_{5} L R C++\beta_{6} C A P S O+\beta_{7} C A P E C+U t
\end{aligned}
$$

where $\beta_{0}$ is the intercept or constant term while Ut is the error term; $\beta_{1}-\beta_{7}$ are parameters to be estimated. 
They are the regression parameters used to determine the impact of each independent or explanatory variable on the dependent variable.

Economic criteria are concerned with determining the consistency of the parameter estimates with economic theories in terms of signs and magnitude. As such, we expect that our parameter estimate must be consistent with economic theory in terms of characters and importance. Theoretically, the relationship between government expenditure and economic growth is expected to be positive. The parameters $\beta_{1}$ to $\beta_{7}$ excluding $\beta 4$ are expected to carry a positive sign after estimation while the intercept might be either positive or negative.

The researchers carried out a unit root test on all the variables employed for this research. This is because most macroeconomic time series have unit roots, and the regression of a non-stationary time series on another non-stationary time series would produce a spurious or nonsensical regression. The Augmented Dickey-Fuller test was used to test the nature of stationarity and determine the order of the integration of the variables. Johansen Co-integration test was employed to test for long-run relationships. At the same time, the Error Correction Model was used to ascertain the short-run impacts and the speed of adjustment from short-run dynamics to long-run equilibrium. The Granger causality test was employed to check the causality between government expenditures and economic growth components.

\section{RESULTS AND DISCUSSION}

Unit Root Test. Data collected were subjected to unit root test, Johansen co-integration, error correction model and granger causality test. The results obtained are as given below.

To test for the presence or absence of unit root in the series used for the empirical study, the Augmented Dickey-Fuller (ADF) test was employed, and the results are as presented below.

Table 1 - Summary of Unit Root Test Result

\begin{tabular}{|l|l|l|l|l|l|l|l|}
\hline \multicolumn{4}{|l|}{ AT LEVEL } & \multicolumn{2}{l|}{ 1st DIFFERENCE } \\
\hline & ADF Stat & $5 \%$ CV & Remark & ADF Stat & $5 \%$ CV & Order & Remark \\
\hline GDPG & -1.693487 & -1.950394 & Non-stationary & -3.928083 & -1.950394 & I(I) & Stationary \\
\hline PDS & -2.494288 & -3.529758 & Non-stationary & -5.427644 & -3.536601 & I(I) & Stationary \\
\hline HLT & -0.806204 & -3.568379 & Non-stationary & -5.497763 & -3.544284 & I(I) & Stationary \\
\hline RC & -3.465118 & -3.529758 & Non-stationary & -6.083601 & -3.540328 & I(I) & Stationary \\
\hline EDU & -0.271168 & -3.548490 & Non-stationary & -5.119377 & -3.548490 & I(I) & Stationary \\
\hline CAPSO & -1.793255 & -3.533083 & Non-stationary & -9.501748 & -3.533083 & I(I) & Stationary \\
\hline CAPEC & -1.750320 & -3.529758 & Non-stationary & -6.478764 & -3.533083 & I(I) & Stationary \\
\hline
\end{tabular}

The unit root test result, as shown in Table 1 above, reveals that none of the variables intended to be used for this research work is stationary at the level since, by comparison, their critical values at $5 \%$ level of significance are more significant than the Dickey-Fuller (ADF) test statistics in absolute terms. However, at the first difference, all the variables became stationary. Thus, all the variables were static and integrated of the first order, I (I). Since the variables were not fixed at the level, Johansen co-integration is conducted to test the long-run relationship.

Co-Integration. Co-integration was used to test for the long-run relationship between the variables used. The researcher adopted the Johansen co-integration test. In Johansen's method, the trace or Maximum Eigenvalue can check for the long-run relationship. The researcher adopted trace statistics to determine the existence of cointegration. Co-integration exists if the trace statistics are more significant than the critical values at a $5 \%$ significance level.

The Johansen co-integration test reveals at least five co-integrating equations. This confirms that long-run relationships exist between the components of government expenditures and the economic growth rate in Nigeria.

Table 2 - Co-integration Test

\begin{tabular}{|l|l|l|l|}
\hline $\begin{array}{l}\text { Hypothesised } \\
\text { Equ. }\end{array}$ & $\begin{array}{l}\text { Trace } \\
\text { Statics }\end{array}$ & $\begin{array}{l}\text { Critical } \\
\text { Values }\end{array}$ & Probability \\
\hline None & 323.5351 & 159.5297 & 0.0000 \\
\hline At most 1 & 217.4822 & 125.6154 & 0.0000 \\
\hline At most 2 & 151.0823 & 95.75366 & 0.0000 \\
\hline At most 3 & 89.91913 & 69.81889 & 0.0006 \\
\hline At most 4 & 54.55312 & 47.85613 & 0.0103 \\
\hline
\end{tabular}


Short-Run Impacts. To examine the short-run impacts, the Error Correction Model was employed. As shown later, the Error Correction model explains the short-run effects, models the long-run consequences, and links the long run and short run using the ECT value. As shown below, the error correction estimates are converted into a system model for simplicity and to incorporate the probability values into our analysis.

Table 3 - Short Run Coefficients

\begin{tabular}{|l|c|c|c|c|}
\hline & Coefficient & Std. Error & t-Statistic & Prob. \\
\hline ECT & -0.411735 & 0.127687 & -3.224555 & 0.0032 \\
\hline GDPG & -0.343849 & 0.150920 & -2.278346 & 0.0305 \\
\hline EDU & -2.730628 & 2.769483 & -0.985970 & 0.3326 \\
\hline AGR & -0.595489 & 1.520345 & -0.391680 & 0.6983 \\
\hline HLT & -0.400646 & 2.171662 & -0.184488 & 0.8550 \\
\hline PDS & 1.450650 & 1.896398 & 0.764950 & 0.4507 \\
\hline RC & 2.474489 & 1.901502 & 1.301334 & 0.2038 \\
\hline CAPSO & -3.083091 & 1.485852 & -2.074965 & 0.0473 \\
\hline CAPEC & 3.497158 & 1.809486 & 1.932680 & 0.0634 \\
\hline C & 0.206707 & 0.787901 & 0.262352 & 0.7950 \\
\hline
\end{tabular}

$\mathrm{R}^{2}=0.47, \mathrm{~F}$-Statistic $=2.785874$, prob. $($ F-statistic $)=0.018167$, Durbin-Watson $=1.88$

Decision Rule. The coefficient of parameters is assumed to be statistically significant if the corresponding probability value is less than $5 \%$.

The Error Correction Model above shows that only government capital expenditures on social service significantly impact the economic growth in Nigeria.

The system equation representing the short-run impacts reveals that recurrent government expenditures on agriculture, education and health have insignificant adverse effects on the GDP growth rate in Nigeria. Specifically, a one billion naira change in government recurrent spending in these sectors will result in an inverse transformation of $\$ 0.60$ billion, $\$ 2.73$ billion and $\$ 0.40$ billion in GDP, respectively. These outcomes do not correspond to economic expectations. However, it relates to Nigeria's poor human capital development and agricultural performance.

Government recurrent expenditures on construction and public debt servicing showed a positive and insignificant impact on the GDP growth. However, debt servicing is regarded as leakages from the domestic economy, so its effect is expected to be negative. On the other hand, recurrent government expenditure on construction is expected to promote economic growth by reducing both direct and indirect cost of production of a private firm and hence, stimulating private investment. Thus, the result correlates with a priori expectations. However, the relationship between construction and economic growth is insignificant, implying that much needs to be done.

The short-run model reveals divergent results from the two components of capital expenditures used for capital expenditures. While capital expenditure on social services is shown to have a negative and significant impact on growth, government capital expenditure on financial services indicates a positive and insignificant effect. This outcome points further to Nigeria's low human capital development and infrastructural decay.

The $\mathrm{R}^{2}$ of 0.47 implies that the model could explain $47 \%$ of GDP changes. It is considered a good fit for the sample. The f-statistics is significant by assuming a probability value less than $5 \%$. This shows that there is a joint influence on the dependent variable. It also implied that the model is a good sample fit for the entire population.

Conclusion on the Short Run model. The shortrun model indicated that only government capital expenditure on social services significantly influenced the Nigerian economy's growth rate. Irrespective of the observed negative effect, the significant impact reveals that a slight improvement in this sector can dramatically impact the economy. This is becoming clearer when we recall that education and health are among the components of capital expenditures on social services. An improvement in the levels of educa- 
tion and health directly affects the labour's productivity which can be relied upon to boost the economy. Government expenditures to other sectors indicated an insignificant impact. The findings suggest, among other things, that government expenditures to these sectors have either been insufficient or have not been efficiently allocated. Nigerian have remained a significant importer of roughly all food commodities, educational infrastructures have continually been dilapidated, investment in the health sector has remained very low, social infrastructure are in- sufficient, and the available ones are not correctly maintained yet, debt stock profile have continued to rise.

Long-Run Impacts. For the sake of this analysis, the long-run impacts are extracted from the upper session of the Error Correction estimates. This shows the changes in the dependent variable due to a difference in the independent variables in the long run. The forecast is as given below.

Table 4 - Long Run Coefficients

\begin{tabular}{|l|c|c|c|c|}
\hline \multicolumn{1}{|c|}{ Variables } & Coefficient & Standard Error & T-statics & Remark \\
\hline Agriculture & -3.252293 & 0.98975 & -3.28598 & Significant \\
\hline Education & -19.86933 & 1.95463 & -10.1653 & Significant \\
\hline Health & 6.193489 & 2.14795 & 2.88344 & Significant \\
\hline Public Debt Servicing & 8.328034 & 1.02367 & 8.13547 & Significant \\
\hline Road and Construction & 8.080619 & 1.15769 & 6.97998 & Significant \\
\hline Capital Exp. On Social Services & -9.654340 & 1.81936 & -5.30644 & Significant \\
\hline Capital Exp. On Economic Services & 10.96006 & 1.11539 & 9.82624 & Significant \\
\hline
\end{tabular}

Decision Rule. The standard error is used to decide the significance of the long-run coefficients. The coefficients are assumed to be statistically insignificant if, in absolute terms, the standard error is greater than the coefficient divided by 2 . That is ifs $\left(\beta_{\mathrm{k}}\right)>\beta_{\mathrm{k}} / 2$. This implies that $\beta_{\mathrm{k}}=0$, that is, no relationship exists between the independent and dependent variables, GDPG.

From table 4 above, we can observe that all the independent variables indicated significant impacts on gross domestic product growth rate. However, recurrent government expenditures on agriculture, education and government capital expenditure on social services, which includes health and education, were shown to have negative impacts whereas, recurrent government expenditures on health, debt servicing, road and construction and capital expenditures on financial services such as agriculture, road, infrastructure etc. indicated positive impacts in the long run.

It is essential to observe the speed of adjustment from the short run disequilibrium to long-run equilibrium; this is shown by the Error Correction term below.

Table 5 - Error Correction Term (ECT)

\begin{tabular}{|c|c|c|c|c|c|}
\hline Variable & coefficient & Standard Error & T-statics & Remark & Prob. Value \\
\hline Error Correction & -0.411735 & 0.127687 & -3.224555 & Significant & 0.0032 \\
\hline
\end{tabular}

The Error Correction Term ties the short run disequilibrium of the co-integrating equations to their long-run static equilibrium. The acceptance of the error correction value depends on three factors. Namely, it must be a negative value indicating a reversal, it must be statistically significant, and thirdly, a fraction. As shown in Table 5, the Error Correction value satisfies these three acceptance criteria. The Error Correction Term of
-0.411735 implies an annual speed of adjustment of $41 \%$ from the short-run dynamics to long-run static equilibrium.

Engle-Granger Causality Test. Engle-Granger causality test was done to check for the direction of causality in the model. The results are presented below. 
Table 6 - Causality Test Value using GDPG as Dependent Variables

\begin{tabular}{|l|c|c|}
\hline \multicolumn{1}{|c|}{ Variables } & Probability & \multicolumn{1}{c|}{ Remark } \\
\hline Agriculture & 0.6953 & No causality \\
\hline Education & 0.3241 & No causality \\
\hline Health & 0.8536 & No causality \\
\hline Debt servicing & 0.4443 & No causality \\
\hline Road and construction & 0.1931 & No causality \\
\hline $\begin{array}{l}\text { Cap. Exp. On social } \\
\text { services }\end{array}$ & 0.0380 & $\begin{array}{c}\text { Causality } \\
\text { exists }\end{array}$ \\
\hline $\begin{array}{l}\text { Cap. Exp. On economic } \\
\text { services }\end{array}$ & 0.0533 & No causality \\
\hline
\end{tabular}

Decision Rule. Causality exists if the probability value corresponding to the variable is less than $5 \%$. The causality test result reveals that unidirectional causality runs from government capital expenditures on social services to GDPG. There is no causal relationship between other components of government-employed and GDPG.

The causality test revealed that GDPG did not make granger causal any of the components of government expenditures employed. However, on the details of government expenditures them- selves, it was seen that a bidirectional causality exists between recurrent government expenditures on health and education. Also, a bidirectional causal relationship exists between recurrent government expenditures on education and government capital expenditures on social services.

Judging from the theoretical frameworks of Keynes and Adolf Wagner, there is no apparent justification for the relevance of either theory in Nigeria. As shown by the causality test, only a single component of government expenditures followed the Keynesian theory. At the same time, there was no causality running from economic growth (increase in economic activities) to government expenditure, as postulated by Adolf Wagner.

Post Estimation Test. Post estimation test was done to determine how seriously the results of this research will be taken. That is, the validity and forecast strength of the results obtained. In doing this, the researcher conducted a normality test

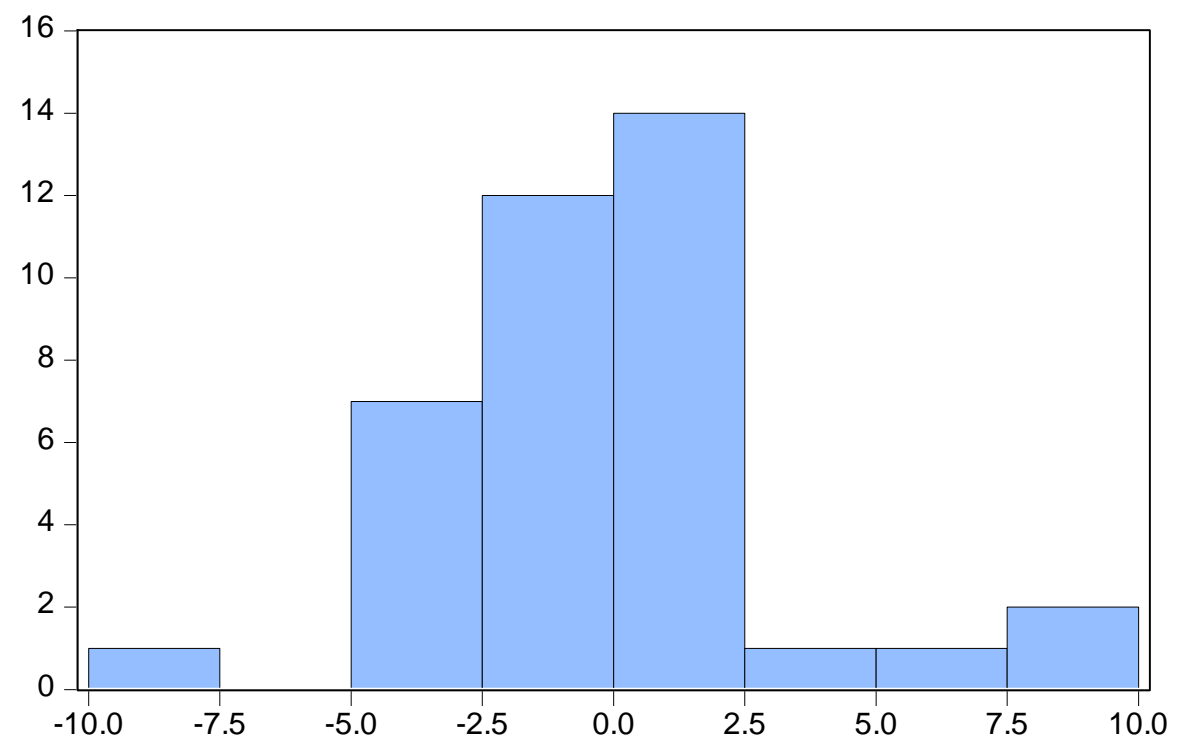

\begin{tabular}{lr}
\multicolumn{2}{l}{ Series: Residuals } \\
Sample 1983 2020 \\
Observations 38 \\
Mean & $4.04 \mathrm{e}-13$ \\
Median & -0.279148 \\
Maximum & 9.886239 \\
Minimum & -9.388229 \\
Std. Dev. & 3.430618 \\
Skewness & 0.363577 \\
Kurtosis & 4.699880 \\
& \\
Jarque-Bera & 5.412381 \\
Probability & 0.066791
\end{tabular}

Figure 4 - Normality Test

The probability value of the Jarque-Bera statistics (approximately 7\%) signifies that the series are typically distributed.

The implication of the study. The study revealed that recurrent government expenditures on agriculture, education, health, public debt servicing, road and construction, and government capital expenditures on financial services have no significant relationship with economic growth in Nigeria. By implication, these expenditures have not impacted the Nigerian economy irrespective of the annual increase in budgetary allocation to these sectors. These findings point to the inefficiency in government spending in Nigeria. Although according to the global competitiveness index reports, Nigeria ranked 120th of 137 countries and territories on the efficiency of government spending in 2018 and 2019, Nigeria ranked 17 of 100 (best) on budget transparency. 
There is, therefore, a need for efficient government spending, accountability and improved budget transparency in Nigeria.

The government have also not paid enough attention to human capital development in Nigeria. This is shown by the negative and insignificant impacts of government expenditures on health and education and the significant negative effect of capital expenditures on social services. Budgetary allocations to health and education have been below $15 \%$ health and $26 \%$ on education, respectively. No wonder Nigeria has continually ranked poorly in the human development index over the years.

The Granger causality test supports the insignificant relationships between the components of government expenditures and economic growth in Nigeria by indicating that except for government capital expenditure on social services, which impacted negatively on the economy, no other component of government expenditures granger causes economic growth; implying that government expenditures have been inefficient in stimulating economic growth in Nigeria.

\section{CONCLUSIONS}

The study analysed the impact of various components of Government Expenditures on Economic Growth in Nigeria for periods between 1981 and 2020 by employing multiple techniques of econometrics analysis such as ADF Unit Root Test, Johansen Co-integration, Error Correction Model and Granger Causality Test.

On employing these techniques, the following findings were made:

1. None of the variables was stationary at a level using the Augmented Dickey-fuller unit root test. This means that all the variables used have unitroots.

2. However, all the variables were stationary at the first difference, which necessitated the application of Johansen co-integration in other to test if there is a long-run relationship between the variables.

3. The Johansen co-integration test revealed at least five co-integrating equations exists between government expenditure and economic growth in Nigeria.

4. The short-run estimate revealed that recurrent government expenditures on education, health and agriculture have a negative and insignificant impact on economic growth. However, government capital expenditures on social services indicated a negative and significant impact on development. In contrast, recurrent government expenditures on public debt servicing, road and construction, and capital expenditures on financial services were shown to have a positive and insignificant impact on economic growth in Nigeria.

5. The Granger Causality revealed that only government capital expenditure on social services caused economic growth in Nigeria.

6. It was observed that all the components of government expenditures have significant impacts on economic growth in the long run.

7. The Error Correction Model indicated an annual speed of adjustment of $41 \%$.

The impact of government expenditures on the economy has drawn much attention in recent years. In Nigeria, the annual increase in budgetary allocation to various sectors has not been efficiently used to achieve critical macroeconomic objectives such as employment, price stability, and economic growth. This has called for empirical investigation. This study finds that the various components of government expenditures have not significantly impacted the economic growth in Nigeria except for capital expenditures on social services, which indicated a negative and significant impact on economic growth. The study concludes that the Nigerian economy is on the wrong path to sustainable growth and development. The study points out the need to improve government spending efficiency and transparency and increase investments in human capital and infrastructural development in Nigeria.

Given the finding from the study, the following is therefore recommended:

1. Capital stock is necessary to drive growth in any economy. This includes roads, bridges, electricity, productive plants and other long-term fixed asset. The availability of these social infrastructures reduces private costs and hence, stimulates private investment and economic growth. When social infrastructures are adequately provided, it will enable the development of other sectors such as the agricultural and industrial sectors when these sectors are stimulated. The problem of unemployment, inflation and balance of trade deficit and other macroeconomic issues will be curbed. It is recommended that govern- 
ment should increase its capital expenditure on both social and economic services as doing so will stimulate economic growth by encouraging private investments, employment, output and economic development.

2. Human capital development is the key to economic growth. This is proven in many economies of the world. Government should pay special attention to improving the level of development of human capital in Nigeria. There should be an increase in the annual investments in the education and health sectors to at least $10 \%$ to $15 \%$ of the total budget.

3. The agricultural sector is paramount for growth; this sector is responsible for feeding the nation (both human and animals), generating foreign exchange and supplying raw materials and labour to the industrial sector. A poorly financed and unmanaged agricultural industry would not perform the above function and remain subsistence. The estimates of this research reveal that government expenditure on agriculture had an insignificant negative impact on the economic growth of Nigeria. It is advised that the government increase her allocation to the agricultural sector and monitor such allocated funds. It is a well-known fact that the problem in Nigeria today is corruption; this is a virus that has deeply eaten Nigeria to its root and has rendered the nation underdeveloped. Therefore, strict monitoring of the use of the fund and adequate punishment for convicted looters should be applied.

4. Debt arises from the unavailability of required capital (money) to carry out a planned expenditure. Funds are not enough because output and activities needed to generate enough funds are limited. To solve the problem of increasing debt stock, the government needs to encourage trade and investment through her monetary and fiscal policies, promote the expansion of and linkage between the agricultural and industrial sectors, supply adequately the required capital stock that is necessary for growth like electricity and good roads etc. and increase the productivity and competitiveness of government-owned cooperation. If we can achieve growth and expansion in our local economy, foreign borrowing will be reduced.

5. Lastly, increasing government expenditures to various sectors without improving the current inefficiencies in government spending will yield no improved result. Therefore, the government is encouraged to allocate funds to its best uses and strictly monitor these processes from budgetary to execution. There is also a need for accountability and transparency in government processes.

\section{REFERENCES}

1. Abu, N., \& Abdullahi, U. (2010). Government expenditure and economic growth in Nigeria, 19702008: A disaggregated analysis. Business and Economics Journal, 1-11.

2. Abutu, U. O., \& Agbede, E. A. (2015). Government expenditure and economic growth in Nigeria: A Cointegration and error correction Modeling. Retrieved from https://mpra.ub.unimuenchen.de/69676/1/MPRA_paper_69676.pdf

3. Adole, S. O., Abraham, O. I., \& Sunday, E. A. (2021). Government expenditure and economic growth in Nigeria. Journal of Economics and Finance, 12(1), 28-38.

4. Agbonkhese, A. O., \& Asekome, M. O. (2014). Impact of public expenditure on the growth of Nigerian economy. European Scientific Journal, 10(28), 219-227.

5. Balami, D. (2006). Macroeconomics: Theory and practice. Abuja: Salawe prints.

6. Bappahyaya, B., Abiah, F. K., \& Bello, F. (2020). Impact of Government Expenditure on Economic Growth: Evidence from Nigeria. European Scientific Journal ESJ, 16(7). doi: 10.19044/esj.2020.v16n7p69

7. Bingilar, P. \& Oyadonghan, J. (2020). Impact of government expenditure on economic growth in Nigeria. World Journal of Finance and Investment Research, 5(1), 21-31

8. Bonmwa, T., \& Ishmael, O. (2017). An empirical analysis of government expenditure and economic growth in Nigeria. Journal of Economics and Development Studies, 5(4), 123-134. 
9. Budgit. (2020). Budget analysis and opportunities. Retrieved from https://yourbudgit.com/data/publications/

10. Central Bank of Nigeria. (2020). Annual Statistical Bulletin. Retrieved from https://www.cbn.gov.ng/documents/statbulletin.asp

11. Echekoba, F. N., \& Chinelo, A. I. (2017). The Impact of Government Expenditure on Nigeria Economic Growth: A Further Disaggregated Approach. NG-Journal of Social Development, 6(3), 34-48. doi: 10.12816/0038069

12. Ebong, F., Ogwumike, F., Udongwo, U., ... Ayodele, O. (2016). Impact of Government Expenditure on Economic Growth in Nigeria: A Disaggregated Analysis. Asian Journal of Economics and Empirical Research, 3(1), 113-121. doi: 10.20448/journal.501/2016.3.1/501.1.113.121

13. Harbison, F. H., \& Myers, C. (1964). Education, manpower and economic growth: Strategies of human resources development. New York: McGraw-Hill.

14. Jaiyeoba, S. (2015). Human Capital Investment and Economic Growth in Nigeria. African Research Review, 9(1), 30. doi: 10.4314/afrrev.v9i1.4

15. Nyasha, S., \& Odhiambo, N. M. (2019). The Impact of Public Expenditure on Economic Growth: A Review of International Literature. Folia Oeconomica Stetinensia, 19(2), 81-101. doi: 10.2478/foli-2019-0015

16. Jhingan, M. L. (2007). Macroeconomic theory. Delhi: Vrinda Publications.

17. Muritala, T., \& Taiwo, A. (2011). Government expenditure and economic growth: epirical evidence from Nigeria. European Journal of Business and Management, 3(9), 18-28

18. Okere, P. A., Uzowuru, L. N., \& Amako. J. C. (2019). Government expenditure and economic growth in Nigeria. International Journal of Economics and Financial Management, 4(2), 29-41.

19. Okoro, A. S. (2013). Government spending and economic growth in Nigeria (1980-2011). Global Journal of Management and Business Research Economics and Commerce, 13(5), 21-29

20. Ebipre, P., \& Eniekezimene, F. (2020). Government expenditure and economic growth in Nigeria. International Journal of Business \& Law Research, 8(3), 63-71.

21. Olulu, R. M., Erhieyovwe, E. K., \& Andrew, U. (2014). Government Expenditures and Economic Growth: The Nigerian Experience. Mediterranean Journal of Social Sciences. doi: 10.5901/mjss.2014.v5n10p89

22. Todaro, M. P., \& Smith, S. C. (2020). Economic development (13th ed.). Harlow: Pearson.

23. United Nations Development Programme. (2021). Human Development Report 2021/22. Retrieved from http://hdr.undp.org/en/content/2021-22-hdr-theme-announcement

24. Yusuf, S. A., Babalola, B., Aninkan, O. D. \& Salako, M. A. (2015). Analysis of impact of sectoral government expenditures on economic growth in Nigeria: Bound test co-integration approach. European Journal of Business and Management, 7(12), 171-184 